\title{
Grape Seed Extract (Vitisvinifera) Alleviate Neurotoxicity and Hepatotoxicity Induced by Lead Acetate in Male Albino Rats
}

\author{
Abeer M. Waggas \\ Department of Biology (Zoology), Faculty of Girls Education, Scientific Department, King Abdulaziz University, \\ Jeddah, Saudi Arabia \\ Email: awagas@kau.edu.sa
}

Received November 10, 2011; revised January 19, 2012; accepted February 2, 2012

\begin{abstract}
Grape seed extracts (GSE) are very potent antioxidant and exhibit numerous interesting pharmacologic activities, including an antioxidant property, and has been suggested to be of use in treatment of several diseases. The present study has been undertaken to investigate the protective and therapeutic effect of GSE against lead-induced neuro and hepatotoxicity in rat. Male albino rats were divided into six groups: the 1st group, rats were injected daily with saline vehicle and served as negative control, the 2nd group (positive control group), the rats were injected (i.p.) with subacute dose $(100 \mathrm{mg} / \mathrm{kg} \mathrm{b} \cdot \mathrm{w} / \mathrm{day})$ of lead acetate (LA). The 3 rd group (protective group), the rats were injected (i.p.) with LA (100 $\mathrm{mg} / \mathrm{kg} \mathrm{b} \cdot \mathrm{w} /$ day) for 7 days after treatment with GSE (100 mg/kg b·w/day) for 3 weeks. The 4 th, 5 th and 6th groups (therapeutics groups), rats were injected (i.p.) with subacut dose $(100 \mathrm{mg} / \mathrm{kg} \mathrm{b} \cdot \mathrm{w} /$ day) of lead acetate for 7 days, then treated with GSE $(100 \mathrm{mg} / \mathrm{kg} \mathrm{b} \cdot \mathrm{w} / \mathrm{day})$ for one, two and three weeks, respectively. The level of norepinephrine (NE), dopamine (DA), serotonin (5-HT) and 5-hydroxyindol acetic acid (5-HIAA) were evaluated in brain regions (cerebellum, brainstem, striatum, cerebral cortex, hypothalamus and hippocampus). The result indicated that the administration of subacute dose of LA (100 mg/kg/day, i.p.) induce a significant decrease in NE, DA, 5-HT and 5-HIAA content in all tested brain regions. Also the obtained data showed significant increase in liver enzymes: serum glutamate oxaloacetate transaminase (GOT), serum glutamate pyruvate transaminase (GPT) and lactate dehydrogenase (LDH) level in group 2 (positive control). There is an improvement in neurotransmitters content. Also the obtained data showed significant increase in liver enzymes of protective (G3) and therapeutics groups (G4, G5 and G6) which received GSE compared with animal group that received lead acetate (G2). This is may be the presence of proanthocyanidins and procyanidins which have antioxidant and free radical scavenging activities. The result suggests that grape seed extract may prevent lead-induced neurotoxicity and hepatotoxicity.
\end{abstract}

Keywords: Grape Seed Extract; Lead; Lead Acetate; Antioxidant; Norepinephrine; Dopamine; Serotonin; 5-Hydroxyindol Acetic Acid; Brain; Liver; Rat

\section{Introduction}

Lead $(\mathrm{Pb})$ is the one of the oldest-established poisons. Knowledge of its general toxic effects stretches back three millennia and knowledge of its effects in children over 100 year [1]. Lead has been used in medicines, paintings, pipes, ammunition and in more recent times in alloys for welding chemical reagent storage. Human beings are also exposed to cadmium, lead and mercury from cigarette smoking. Given all that, the concentration of this metal in the environment and our exposure to it have increased significantly during human history especially in the latest centuries $[2,3]$.

Lead-exposure occurs through the respiratory and gastrointestinal systems and lead which is ingested and ab- sorbed is stored mainly in soft tissues and bone. Several reports have indicated that lead can cause neurological, hematological, gastrointestinal, reproductive, circulatory and immunological pathologies, all of them related to the dose and the amount of time of lead exposure [4-6]. As the main target for lead toxicity is the CNS, the brain is the organ most studied in lead toxicity. In the CNS, symptoms of lead poisoning include dullness, forgetfulness, irritability, poor attention span, headache, fatigue, impotence, dizziness, and depression. Lead encephalopathy, a progressive and potentially fatal degeneration of the brain, is the most severe neurological effect of lead poisoning $[7,8]$.

Plant material in the human diet contain a large number of natural compounds, which may be of benefit in 
protecting the body against the development of neurontoxicity. One of the first plant with constituents reputed to possess neuroprotective properties was grape. Grapevine (Vitisvinifera), is cultivated today in all temperature regions of the world $[9,10]$. Its seeds contain several active components including flavonoids, poly phenols, anthocyanins, proanthicyanidins and procyanidines, gape seeds extract (GSE) contain 70\% - 95\% standardized proanthocyanidins [11]. A variety of naturally occurring grape seed extract have been found to have beneficial effects on health, and these compounds drawn attention because of their relative safeness and accumulated evidence of physiological properties in animals and human [12]. Oil produced from grape seeds is considered a rich source poly phenolic with strong antioxidant activity, chemopreventive, anti-inflammatory, anti-microbial and anti-cancer effects [13-15].

However, lead exposure continues to be a major public health problem, particularly in USA and also in Third World nations [16]. Also, lead cause adverse effects to hepatic cells because after lead exposure, liver is one of the major organs involved in the storage, biotransformation and detoxification. As a result, research into the toxic effects of lead continues and the last decade has been particularly fruitful in providing new information on manifold influences of this metal. Therefore, the present study attention is focused on whether the administration of grape seeds extract to rats could protect and therapeutic against lead-induced toxicity.

\section{Materials and Methods}

Chemicals: Lead acetate $\left[\left(\mathrm{C}_{2} \mathrm{H}_{3} \mathrm{O}_{2}\right) 2 \mathrm{~Pb} \cdot 3 \mathrm{H}_{2} \mathrm{O}, \mathrm{Pb}\right]$ was obtained from Sigma Chemical Co. (St Louis, Mo, USA). All other chemicals used were of analytical grade.

Preparation of grape seed extract: Grapes as large clusters with red berries, were bought from a local supermarket in Saudi Arabia (Jeddah) and identified as Vitisvinifera. Grape seeds were removed from the grapes, air dried for 1 week. The ethanolic extract was prepared by soaking 100 gm of grape seeds powdered in $300 \mathrm{ml}$ ethanol $(95 \%)$ shaking $(24 \mathrm{~h})$ then covered by a piece of aluminum foil and kept in refrigerator. The infusion was filtered by a piece of double gauze and the filtrate was centrifuged at $3000 \mathrm{rpm}$ for 10 minutes, then the supernatant (ethanol) was evaporated using a rotatory evaporator apparatus attached with vacuum pump. The $100 \mathrm{gm}$ of dried grape seeds powder yield 26.7 gm ethanol [1719]. Preparation of subacute dose of lead acetate (LA): Dissolving $100 \mathrm{~g}$ of lead acetate in $1 \mathrm{~L}$ saline $(100 \mathrm{mg} / \mathrm{ml})$ [20].

Animals: Tow-month old (180 - 200 g body weight) male albino rats (Rattus norvegicus) were selected from animal house of king Fahd of medical researchers in Jeddah, Saudi Arabia. The animals were housed under con- trolled environment conditions ( $12 \mathrm{~h} \mathrm{light/dark} \mathrm{cycle)} \mathrm{at}$ a temperature of $25^{\circ} \mathrm{C}+10^{\circ} \mathrm{C}$ and humidity of $60 \%+5 \%$ and fed standard diet and water Ad libitum for the experimental period.

Experimental design: After an acclimation period of one week, 36 rats were divided randomly into six groups (6 rats/group). The 1st group (G1) served as negative control (rats were injected intraperitonally (i.p.) with $\mathrm{ml}$ of normal saline for 7 days. The 2 nd group, (positive control group) were injected (i.p.) with subacute dose of lead acetate $(100 \mathrm{mg} / \mathrm{kg} \mathrm{b} \cdot \mathrm{w} /$ day) for 7 days. The 3rd group, (protective group) was administrated orally GSE $(100 \mathrm{mg} / \mathrm{kg} \mathrm{b} \cdot \mathrm{w} /$ day) for three weeks [19-22] then injected (i.p.) with subacute dose of LA $(100 \mathrm{mg} / \mathrm{kg} \mathrm{b} \cdot \mathrm{w} /$ day) for 7 days. The 4th, 5th and 6th groups (therapeutic groups), were injected (i.p.) with subacut dose (100 $\mathrm{mg} / \mathrm{kg} \mathrm{b} \cdot \mathrm{w} /$ day) of lead acetate for 7 days, then treated daily with single dose of GSE (100 mg/ $\mathrm{kg} \mathrm{b} \cdot \mathrm{w} /$ day $)$ for one, two and three weeks respectively.

After the end of experimental period [one week (G1, G2), two weeks (G4), three weeks (G5) and four weeks (G3, G6)] the animals were slaughtered and the brain tissue of each rat was excised rapidly and carefully, then the different regions of brain (cerebellum, brainstem, striatum, cerebral cortex, hypothalamus and hippocampus) were dissected on dry ice glass plate according Glowinski and Iversen, [23]. The different regions of brain under study were wiped dry with a filter paper weighed, wrapped in plastic film followed by aluminum foil and frozen in dry ice for neurochemical analysis. Blood samples were collected from all rats within different treatment groups by retro bulbar method into heparinzed tubes and the plasma was separated by centerfugation at $2500 \mathrm{rpm}$ for $15 \mathrm{~min}$. plasma was frozen at $-20^{\circ} \mathrm{C}$ for biochemical analysis (liver function).

Neurochemical analysis: Norepinephrine (NE), dopamine (DA) and serotonin (5-HT) were extracted and estimated according to the method of Chang, [24] modified by Ciarlone, [25]. 5-HIAA was estimated according to the method described by Miller et al. [26]. The fluorescence was measured in Jenway 6200 fluorometer.

Blood parameters determination: Glutamate oxaloacetate transaminase (GOT) and glutamate pyruvate (GPT) were determined by the method of Reitman and Frankel, [27]. Lactate dehydrogenase (LDH) activity was estimated in serum by the method of Kornberg, [28,29].

Statistical analysis: The results are expressed as mean + S.E. for six rats in each group. Differences between groups were assessed by student's $t$ test using the SPSS version 7.5 software package for Windows, USA. The level of significance was set at $\mathrm{P}<0.05$.

\section{Results}

The effects of lead acetate (LA) and GSE-protective and 
therapeutic on the monoamines of rats are presented in Tables 1-4. Statistical analysis of data in this study showed that there are significant difference between group concerning the level of NE in different regions of brain under study (cerebellum, brainstem, striatum, cerebral cortex, hypothalamus and hippocampus) Table 1. The positive control group (G2) showed the significant lowest mean level of NE in all tested brain regions compared to the negative control group (G1). Whereas the significant highest mean level of NE in all brain regions were detected in protective group (G3) and therapeutic group (G6) compared to G2. The result in Table 1 showed that, the level of $\mathrm{NE}$ is increased in all regions of brain in therapeutic groups (G4 and G5).

Table 1. Protective and therapeutic effects of grape (Vitisvinifera ) seeds extract (100 mg/kg i.p.) on norepinephrine (NE) content in different brain regions in male albino rats treated with lead acetate $(100 \mathrm{mg} / \mathrm{kg}$ i.p.).

\begin{tabular}{|c|c|c|c|c|c|c|c|}
\hline \multicolumn{2}{|c|}{$\begin{array}{c}\text { Brain regions } \\
\begin{array}{c}\text { Time of } \\
\text { decapitation }\end{array}\end{array}$} & $\begin{array}{c}\text { Cerebellum } \\
\mu \mathrm{g} / \mathrm{g}\end{array}$ & $\begin{array}{c}\text { Brainstem } \\
\mu \mathrm{g} / \mathrm{g}\end{array}$ & $\begin{array}{c}\text { Striatum } \\
\mu \mathrm{g} / \mathrm{g}\end{array}$ & $\begin{array}{c}\text { Cerebral cortex } \\
\mu \mathrm{g} / \mathrm{g}\end{array}$ & $\begin{array}{c}\text { Hypothalamus } \\
\mu \mathrm{g} / \mathrm{g}\end{array}$ & $\begin{array}{c}\text { Hippocampus } \\
\mu \mathrm{g} / \mathrm{g}\end{array}$ \\
\hline \multirow{6}{*}{ 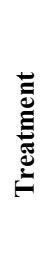 } & G1 & $281.33 \pm 10.11$ & $181.13 \pm 9.00$ & $701.33 \pm 12.32$ & $104.11 \pm 0.91$ & $651.88 \pm 11.25$ & $622.14 \pm 15.24$ \\
\hline & G2 & $120.66 \pm 10.11^{\mathrm{A}}$ & $101.55 \pm 8.84^{\mathrm{A}}$ & $433.21 \pm 6.32^{\mathrm{A}}$ & $58.22 \pm 1.22^{\mathrm{A}}$ & $451.17 \pm 12.31^{\mathrm{A}}$ & $400.32 \pm 11.25^{\mathrm{A}}$ \\
\hline & G3 & $271.11 \pm 12.33^{\mathrm{B}}$ & $166.33 \pm 8.21^{\mathrm{B}}$ & $677.33 \pm 7.36^{\mathrm{B}}$ & $100.11 \pm 1.04^{\mathrm{B}}$ & $600.22 \pm 15.13^{\mathrm{B}}$ & $592.22 \pm 16.33^{\mathrm{B}}$ \\
\hline & G4 & $160.31 \pm 13.32^{\mathrm{A}-\mathrm{B}}$ & $133.33 \pm 4.56^{\mathrm{A}-\mathrm{B}}$ & $551.01 \pm 8.54^{\mathrm{A}-\mathrm{B}}$ & $79.25 \pm 1.02^{\mathrm{A}-\mathrm{B}}$ & $505.31 \pm 10.36^{\mathrm{A}-\mathrm{B}}$ & $480.33 \pm 6.66^{\mathrm{A}-\mathrm{B}}$ \\
\hline & G5 & $201.60 \pm 9.02^{\mathrm{A}-\mathrm{B}}$ & $160.60 \pm 9.91^{\mathrm{A}-\mathrm{B}}$ & $656.22 \pm 9.52^{\mathrm{A}-\mathrm{B}}$ & $89.00 \pm 1.20^{\mathrm{A}-\mathrm{B}}$ & $591.22 \pm 13.33^{\mathrm{A}-\mathrm{B}}$ & $531.11 \pm 8.25^{\mathrm{A}-\mathrm{B}}$ \\
\hline & G6 & $270.30 \pm 9.21^{\mathrm{B}}$ & $183.31 \pm 8.54^{\mathrm{B}}$ & $691.54 \pm 8.45^{\mathrm{B}}$ & $101.11 \pm 1.02^{\mathrm{B}}$ & $666.24 \pm 9.22^{\mathrm{B}}$ & $606.31 \pm 7.32^{\mathrm{B}}$ \\
\hline
\end{tabular}

A. Statically significant $(\mathrm{P}<0.05)$ compared to group 1 ; ${ }^{\mathrm{B}}$ : Statically significant $(\mathrm{P}<0.05)$ compared to group 2; G1: Negative control rats were treated with saline; G2: Positive control rats were treated with LA; G3: Rats were treated with LA for 7 days after GSE treated for 3 weeks (protective group); G4: Rats were treated with GSE for 1 weeks after LA injection for 7 days (therapeutic group); G5: Rats were treated with GSE for 2 weeks after LA injection for 7 days (therapeutic group); G6: Rats were treated with GSE for 3 weeks after LA injection for 7 days (therapeutic group).

Table 2. Protective and therapeutic effects of grape (Vitisvinifera) seeds extract (100 mg/kg i.p.) on dopamine (DA) content in different brain regions in male albino rats treated with lead acetate $(100 \mathrm{mg} / \mathrm{kg}$ i.p.).

\begin{tabular}{|c|c|c|c|c|c|c|c|}
\hline \multicolumn{2}{|c|}{$\begin{array}{c}\text { Brain regions } \\
\text { Time of } \\
\text { decapitation }\end{array}$} & $\begin{array}{c}\text { Cerebellum } \\
\qquad \mu \mathrm{g} / \mathrm{g}\end{array}$ & $\begin{array}{c}\text { Brainstem } \\
\mu \mathrm{g} / \mathrm{g}\end{array}$ & $\begin{array}{l}\text { Striatum } \\
\mu \mathrm{g} / \mathrm{g}\end{array}$ & $\begin{array}{c}\text { Cerebral cortex } \\
\mu \mathrm{g} / \mathrm{g}\end{array}$ & $\begin{array}{c}\text { Hypothalamus } \\
\qquad \mathrm{g} / \mathrm{g}\end{array}$ & $\begin{array}{c}\text { Hippocampus } \\
\mu \mathrm{g} / \mathrm{g}\end{array}$ \\
\hline \multirow{6}{*}{ 苞 } & G1 & $281.11 \pm 10.05$ & $211.21 \pm 6.33$ & $674.25 \pm 9.22$ & $117.66 \pm 1.35$ & $670.42 \pm 6.87$ & $622.37 \pm 11.11$ \\
\hline & G2 & $191.31 \pm 4.76^{\mathrm{A}}$ & $102.71 \pm 2.25^{\mathrm{A}}$ & $433.67 \pm 8.25^{\mathrm{A}}$ & $62.54 \pm 1.22^{\mathrm{A}}$ & $333.91 \pm 12.39^{\mathrm{A}}$ & $311.92 \pm 9.12^{\mathrm{A}}$ \\
\hline & G3 & $222.02 \pm 4.11^{\mathrm{B}}$ & $151.35 \pm 7.26^{\mathrm{B}}$ & $666.21 \pm 8.35^{\mathrm{B}}$ & $100.73 \pm 1.74^{\mathrm{B}}$ & $612.29 \pm 7.17^{\mathrm{B}}$ & $606.51 \pm 13.21^{\mathrm{B}}$ \\
\hline & G4 & $201.12 \pm 2.13^{\mathrm{A}}$ & $120.31 \pm 9.35^{\mathrm{A}}$ & $522.35 \pm 10.25^{\mathrm{A}-\mathrm{B}}$ & $80.11 \pm 0.25^{\mathrm{A}-\mathrm{B}}$ & $488.88 \pm 8.39^{\mathrm{A}-\mathrm{B}}$ & $491.40 \pm 7.27^{\mathrm{A}-\mathrm{B}}$ \\
\hline & G5 & $260.31 \pm 6.46^{\mathrm{A}-\mathrm{B}}$ & $140.31 \pm 2.71^{\mathrm{A}-\mathrm{B}}$ & $599.37 \pm 20.54^{\mathrm{A}-\mathrm{B}}$ & $103.58 \pm 1.85^{\mathrm{A}-\mathrm{B}}$ & $580.11 \pm 10.10^{\mathrm{A}-\mathrm{B}}$ & $570.11 \pm 11.23^{\mathrm{A}-\mathrm{B}}$ \\
\hline & G6 & $290.11 \pm 7.54^{\mathrm{B}}$ & $191.21 \pm 5.31^{\mathrm{B}}$ & $640.33 \pm 6.44^{\mathrm{B}}$ & $120.11 \pm 1.91^{\mathrm{B}}$ & $681.31 \pm 7.59^{\mathrm{B}}$ & $677.45 \pm 9.59^{\mathrm{B}}$ \\
\hline
\end{tabular}

A: Statically significant $(\mathrm{P}<0.05)$ compared to group 1 ; ${ }^{\mathrm{B}}$ : Statically significant $(\mathrm{P}<0.05)$ compared to group 2; G1: Negative control rats were treated with saline; G2: Positive control rats were treated with LA; G3: Rats were treated with LA for 7 days after GSE treated for 3 weeks (protective group); G4: Rats were treated with GSE for 1 weeks after LA injection for 7 days (therapeutic group); G5: Rats were treated with GSE for 2 weeks after LA injection for 7 days (therapeutic group); G6: Rats were treated with GSE for 3 weeks after LA injection for 7 days (therapeutic group).

Table 3. Protective and therapeutic effects of grape (Vitisvinifera) seeds extract (100 mg/kg i.p.) on serotonin (5-HT) content in different brain regions in male albino rats treated with lead acetate $(100 \mathrm{mg} / \mathrm{kg}$ i.p. $)$.

\begin{tabular}{|c|c|c|c|c|c|c|c|}
\hline \multicolumn{2}{|c|}{ Brain regions } & \multirow{2}{*}{$\begin{array}{c}\text { Cerebellum } \\
\mu \mathrm{g} / \mathrm{g}\end{array}$} & \multirow{2}{*}{$\begin{array}{c}\text { Brainstem } \\
\quad \mu \mathrm{g} / \mathrm{g}\end{array}$} & \multirow{2}{*}{$\begin{array}{c}\text { Striatum } \\
\mu \mathrm{g} / \mathrm{g}\end{array}$} & \multirow{2}{*}{$\begin{array}{c}\text { Cerebral cortex } \\
\mu \mathrm{g} / \mathrm{g}\end{array}$} & \multirow{2}{*}{$\begin{array}{c}\text { Hypothalamus } \\
\mu \mathrm{g} / \mathrm{g}\end{array}$} & \multirow{2}{*}{$\begin{array}{c}\text { Hippocampus } \\
\mu \mathrm{g} / \mathrm{g}\end{array}$} \\
\hline Time & itation & & & & & & \\
\hline \multirow{6}{*}{ 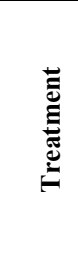 } & G1 & $261.99 \pm 8.61$ & $191.56 \pm 4.81$ & $701.28 \pm 4.66$ & $120.20 \pm 1.12$ & $666.85 \pm 8.45$ & $612.97 \pm 12.84$ \\
\hline & G2 & $160.33 \pm 9.11^{\mathrm{A}}$ & $95.33 \pm 5.62^{\mathrm{A}}$ & $488.11 \pm 11.82^{\mathrm{A}}$ & $71.11 \pm 1.51^{\mathrm{A}}$ & $400.23 \pm 14.74^{\mathrm{A}}$ & $425.38 \pm 12.46^{\mathrm{A}}$ \\
\hline & G3 & $251.90 \pm 7.52^{\mathrm{B}}$ & $173.24 \pm 1.29^{\mathrm{B}}$ & $686.32 \pm 7.24^{\mathrm{B}}$ & $118.21 \pm 1.11^{\mathrm{B}}$ & $631.42 \pm 17.51^{\mathrm{B}}$ & $580.11 \pm 12.73^{\mathrm{B}}$ \\
\hline & G4 & $190.31 \pm 4.25^{\mathrm{A}-\mathrm{B}}$ & $100.51 \pm 3.33^{\mathrm{A}}$ & $511.33 \pm 12.72^{\mathrm{A}}$ & $81.21 \pm 0.98^{\mathrm{A}}$ & $490.11 \pm 7.31^{\mathrm{A}-\mathrm{B}}$ & $512.11 \pm 8.16^{\mathrm{A}-\mathrm{B}}$ \\
\hline & G5 & $201.39 \pm 7.39^{\mathrm{A}-\mathrm{B}}$ & $155.24 \pm 7.44^{\mathrm{A}-\mathrm{B}}$ & $612.76 \pm 11.54^{\mathrm{A}-\mathrm{B}}$ & $110.31 \pm 0.25^{\mathrm{A}-\mathrm{B}}$ & $530.30 \pm 12.25^{\mathrm{A}-\mathrm{B}}$ & $590.55 \pm 17.25^{\mathrm{A}-\mathrm{B}}$ \\
\hline & G6 & $270.55 \pm 7.22^{\mathrm{B}}$ & $201.33 \pm 7.25^{\mathrm{B}}$ & $715.09 \pm 7.11^{\mathrm{B}}$ & $125.21 \pm 1.99^{\mathrm{B}}$ & $671.77 \pm 10.06^{\mathrm{B}}$ & $640.21 \pm 8.11^{\mathrm{B}}$ \\
\hline
\end{tabular}

A: Statically significant $(\mathrm{P}<0.05)$ compared to group $1 ;{ }^{\mathrm{B}}$ : Statically significant $(\mathrm{P}<0.05)$ compared to group 2 ; G1: Negative control rats were treated with saline; G2: Positive control rats were treated with LA; G3: Rats were treated with LA for 7 days after GSE treated for 3 weeks (protective group); G4: Rats were treated with GSE for 1 weeks after LA injection for 7 days (therapeutic group); G5: Rats were treated with GSE for 2 weeks after LA injection for 7 days (therapeutic group); G6: Rats were treated with GSE for 3 weeks after LA injection for 7 days (therapeutic group). 
As shown in Table 2 the positive control group (G2) recorded a significant decrease in the DA content in cerebellum $(191.31 \mu \mathrm{g} / \mathrm{g})$, brainstem $(102.71 \mu \mathrm{g} / \mathrm{g})$, striatum (433.67 $\mu \mathrm{g} / \mathrm{g})$, cerebral cortex $(62.54 \mu \mathrm{g} / \mathrm{g})$, hypothalamus $(333.91 \mu \mathrm{g} / \mathrm{g})$ and hippocampus $(311.92 \mu \mathrm{g} / \mathrm{g})$ compared to the negative control group (G1). Whereas the significant highest mean level of DA content were detected in protective group (G3) and therapeutic group (G6), compared to G2. However, the level of DA in all samples of brain under study from the therapeutic groups (G4 and G5) still increased except in cerebellum (201.12 $\mu \mathrm{g} / \mathrm{g})$ and brainstem $(120.31 \mu \mathrm{g} / \mathrm{g})$ of G4 group compared to $\mathrm{G} 2$ group.

The data presented in Table 3 reveled that LA treatment $(\mathrm{G} 2)$ caused inhibition in 5-HT content in different brain regions under study compared to negative control group (G1). Where there was a significant increase in 5-HT content in protective group (G3) and therapeutic group (G6) in all tested brain regions compared to positive control group G2. A significant increase in 5-HT content in cerebellum (190.31 \& $201.39 \mu \mathrm{g} / \mathrm{g})$, brainstem (155.24 $\mu \mathrm{g} / \mathrm{g})$, striatum $(612.76 \mu \mathrm{g} / \mathrm{g})$ cerebral cortex (110.31 $\mu \mathrm{g} / \mathrm{g})$, hypothalamus $(490.11 \& 530.30 \mu \mathrm{g} / \mathrm{g})$ and hippocampus $(512.11 \& 590.55 \mu \mathrm{g} / \mathrm{g})$ was also found in thera- peutic groups (G4 and G5) compared to G2 except in: brainstem $(100.51 \mu \mathrm{g} / \mathrm{g})$, striatum $(511.33 \mu \mathrm{g} / \mathrm{g})$ and cerebral cortex $(81.21 \mu \mathrm{g} / \mathrm{g})$ of G4 group was not significant.

The positive control group ( $100 \mathrm{mg} / \mathrm{kg} \mathrm{b} \cdot \mathrm{w} /$ day for 7 days) showed the same trend in the level of 5-HIAA in all regions of brain under study compared to G1 (Table 4). However, protective group (G3) recorded significantly increase in 5-HIAA content in all brain regions compared to G2 group but this increase was not significant compared to G1. An increase was also found in therapeutic groups (G4, G5 and G6) compared to G2 except in cerebellum $(145.14 \mu \mathrm{g} / \mathrm{g})$ and brain stem $(102.11 \mu \mathrm{g} / \mathrm{g})$ of $\mathrm{G} 4$.

Additionally, GOT and GPT levels indifferent groups reveal significant differences. LA induced significant increase in GPT (62.31), GOT (66.51) levels compared to negative control group $(18.77,25.11)$ respectively. Whereas the level of GPT $(33.33,26.76,20.88)$ and GOT (50.34, $41.51,30.18$ ) in G4, G5 and G6 were decrease levels when comparing the groups G2 which treated with LA. Moreover, there is a significant increase in $\mathrm{LDH}$ level in positive control group (G2) compared to G1. LDH level significantly decreased in G3 (protective group) and therapeutic groups (G5, G6) compared to G2, while G4 was not recorded significant change compared to G2 (Table 5).

Table 4. Protective and therapeutic effect of grape (Vitisvinifera) seeds extract $(100 \mathrm{mg} / \mathrm{kg}$ i.p.) on 5-hydroxyindolacetic acid (5-HIAA) content in different brain regions in malealbino rats treated with lead acetate (100 $\mathrm{mg} / \mathrm{kg}$ i.p.).

\begin{tabular}{|c|c|c|c|c|c|c|c|}
\hline \multicolumn{2}{|c|}{$\begin{array}{c}\text { Brain regions } \\
\begin{array}{c}\text { Time of } \\
\text { decapitation }\end{array}\end{array}$} & \multirow{2}{*}{$\begin{array}{c}\begin{array}{c}\text { Cerebellum } \\
\boldsymbol{\mu g} / \mathbf{g}\end{array} \\
261.71 \pm 4.44\end{array}$} & \multirow{2}{*}{$\begin{array}{c}\begin{array}{c}\text { Brainstem } \\
\boldsymbol{\mu g} / \mathbf{g}\end{array} \\
185.52 \pm 7.25\end{array}$} & \multirow{2}{*}{$\begin{array}{c}\begin{array}{c}\text { Striatum } \\
\boldsymbol{\mu g} / \mathbf{g}\end{array} \\
700.59 \pm 9.85\end{array}$} & \multirow{2}{*}{$\begin{array}{c}\begin{array}{c}\text { Cerebral cortex } \\
\boldsymbol{\mu g} / \mathbf{g}\end{array} \\
121.81 \pm 1.11\end{array}$} & \multirow{2}{*}{$\begin{array}{c}\begin{array}{c}\text { Hypothalamus } \\
\boldsymbol{\mu g} / \mathbf{g}\end{array} \\
661.81 \pm 9.31\end{array}$} & \multirow{2}{*}{$\begin{array}{c}\begin{array}{c}\text { Hippocampus } \\
\boldsymbol{\mu g} / \mathbf{g}\end{array} \\
641.92 \pm 7.62\end{array}$} \\
\hline \multirow{6}{*}{ 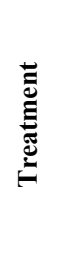 } & G1 & & & & & & \\
\hline & G2 & $121.01 \pm 4.81^{\mathrm{A}}$ & $99.05 \pm 2.41^{\mathrm{A}}$ & $460.17 \pm 5.82^{\mathrm{A}}$ & $80.22 \pm 1.19^{\mathrm{A}}$ & $401.53 \pm 9.65^{\mathrm{A}}$ & $450.50 \pm 9.11^{\mathrm{A}}$ \\
\hline & G3 & $277.17 \pm 9.71^{\mathrm{B}}$ & $177.27 \pm 9.12^{\mathrm{B}}$ & $681.63 \pm 12.19^{\mathrm{B}}$ & $115.50 \pm 1.22^{\mathrm{B}}$ & $622.11 \pm 12.14^{\mathrm{B}}$ & $616.22 \pm 8.25^{\mathrm{B}}$ \\
\hline & G4 & $145.14 \pm 11.87^{\mathrm{A}}$ & $102.11 \pm 8.64^{\mathrm{A}}$ & $522.22 \pm 14.44^{\mathrm{A}-\mathrm{B}}$ & $97.21 \pm 2.14^{\mathrm{A}-\mathrm{B}}$ & $580.80 \pm 14.54^{\mathrm{A}-\mathrm{B}}$ & $515.23 \pm 10.11^{\mathrm{A}-\mathrm{B}}$ \\
\hline & G5 & $191.52 \pm 8.25^{\mathrm{A}-\mathrm{B}}$ & $161.41 \pm 4.22^{\mathrm{A}-\mathrm{B}}$ & $621.21 \pm 12.25^{\mathrm{A}-\mathrm{B}}$ & $110.98 \pm 1.02^{\mathrm{A}-\mathrm{B}}$ & $621.12 \pm 11.51^{\mathrm{A}-\mathrm{B}}$ & $606.66 \pm 9.47^{\mathrm{A}-\mathrm{B}}$ \\
\hline & G6 & $250.07 \pm 4.32^{\mathrm{B}}$ & $202.18 \pm 4.58^{\mathrm{B}}$ & $712.11 \pm 8.24^{\mathrm{B}}$ & $122.44 \pm 1.04^{\mathrm{B}}$ & $670.21 \pm 10.21^{\mathrm{B}}$ & $672.11 \pm 12.11^{\mathrm{B}}$ \\
\hline
\end{tabular}

A: Statically significant $(\mathrm{P}<0.05)$ compared to group 1 ; ${ }^{\mathrm{B}}$ : Statically significant $(\mathrm{P}<0.05)$ compared to group $2 ;$ G1: Negative control rats were treated with saline; G2: Positive control rats were treated with LA; G3: Rats were treated with LA for 7 days after GSE treated for 3 weeks (protective group); G4: Rats were treated with GSE for 1 weeks after LA injection for 7 days (therapeutic group); G5: Rats were treated with GSE for 2 weeks after LA injection for 7 days (therapeutic group); G6: Rats were treated with GSE for 3 weeks after LA injection for 7 days (therapeutic group).

Table 5. Protective and therapeutic effect of grape (Vitisvinifera) seeds extract $(100 \mathrm{mg} / \mathrm{kg}$ i.p.) on liver enzymes level in male albino rats treated with lead acetate $(100 \mathrm{mg} / \mathrm{kg}$ i.p. $)$.

\begin{tabular}{|c|c|c|c|}
\hline Treatment groups & $\begin{array}{c}\text { SGPT } \\
\left(\mathrm{IU} \mathrm{I}^{-1}\right)\end{array}$ & $\begin{array}{l}\text { SGOT } \\
\left(\mathrm{IU} \mathrm{I}^{-1}\right)\end{array}$ & $\begin{array}{c}\text { LDH } \\
\text { (nmol NADPH } \\
\text { oxidized } \text { min }^{-1} \mathrm{mg}^{-1} \text { protein) }\end{array}$ \\
\hline G1 & $18.77 \pm 0.912$ & $25.11 \pm 0.733$ & $295.31 \pm 8.31$ \\
\hline G2 & $62.31 \pm 1.225^{\mathrm{A}}$ & $66.51 \pm 1.884^{\mathrm{A}}$ & $425.81 \pm 5.42^{\mathrm{A}}$ \\
\hline G3 & $19.21 \pm 0.713^{\mathrm{B}}$ & $25.33 \pm 0.312^{\mathrm{B}}$ & $325.31 \pm 10.32^{\mathrm{B}}$ \\
\hline G4 & $33.33 \pm 0.963^{\mathrm{A}-\mathrm{B}}$ & $50.34 \pm 2.335^{\mathrm{A}-\mathrm{B}}$ & $381.11 \pm 8.77^{\mathrm{A}}$ \\
\hline G6 & $20.88 \pm 1.532^{\mathrm{B}}$ & $30.18 \pm 1.592^{\mathrm{B}}$ & $310.33 \pm 3.45^{\mathrm{B}}$ \\
\hline
\end{tabular}

\footnotetext{
A: Statically significant $(\mathrm{P}<0.05)$ compared to group $1 ;{ }^{\mathrm{B}}$ : Statically significant $(\mathrm{P}<0.05)$ compared to group 2 G1: Control rats were treated with saline; G2: Control rats were treated with LA; G3: Rats were treated with LA for 7 days after GSE treated for 3 weeks; G4: Rats were treated with GSE for 1 weeks after LA injection for 7 days; G5: Rats were treated with GSE for 2 weeks after LA injection for 7 days; G6: Rats were treated with GSE for 3 weeks after LA injection for 7 days.
} 


\section{Discussion}

Lead $(\mathrm{Pb})$ is a one of the major heavy metals known to be toxic to mammals, lead poisoning is associated with physiological problem such as mental retardation, learning disabilities, low birth weight and behavioral problems [30-32]. Acute changes in neuropsychological function have been seen in inorganic lead workers. These effects are seen in visual/motor performance, memory, decreased hearing, attention and verbal [33-35]. These effects can be detected in workers with blood lead levels of $>50 \mu \mathrm{g} / 100 \mathrm{ml}$ [36]. In particular, lead can cause some serious damage in the brain and oxidative stress has been proposed as a potential mechanism in the pathogenesis of lead toxicity [37].

The direct neurotoxic actions of lead include apoptosis (programmed cell death), excitotoxicity affecting neurontransmitter storage and release and altering neurotransmitter receptors, mitochondria, second messengers, cerebrovascular endothelial cells, and both astroglia and oligodendroglia. Lead also causes toxic effects by oxidative stress and by either directlyorindirectly-produced lipid peroxidation. Lead alters lipid metabolism, inhibits superoxide dismutase and enhances lipid peroxidation in the brains of developing rats [16,32].

From the present result it is clear that the administration (i.p.) of subacute dose $(100 \mathrm{mg} / \mathrm{kg} \mathrm{b} \cdot \mathrm{w} /$ day $)$ induce a significant decrease in NE, DA, 5-HT and 5-HIAA content in all tested brain regions, and the rats showed ataxia and skeletal muscle weakness.

The neurotoxic effect of $\mathrm{Pb}$ on the catecholaminergic and cholinergic nervous system has been investigated using a rat model of lead exposure. The biochemical effect of lead on brain neurochemistry was depending on the degree and duration of $\mathrm{Pb}$ exposure. Within the catecholaminergic nervous system, lead exposure resulted in alterations in concentrations of the transmitters, NE and DA [38-40]. Previous studies carried by Nachshen, [41] and Minnema et al. [42] indicated that $\mathrm{Pb}$-induced increase in spontaneous transmitter release in apparently due to either an increase in intraneuronal ionized calcium or the stimulation by $\mathrm{Pb}$ of $\mathrm{Ca}$-activated molecules mediating transmitter release. In addition, Gill et al. [40] reported that lead exerts its neurotoxic effects by interfereing with $\mathrm{Ca}^{2+}$ calmoduline mediated neurotransmitter release that is eventually responsible for behavioural impairment. Lead also disrupts the activity of synaptotagmin a protein localized in the synaptic terminal that appear to be important for transmitter release [43]. On other hand Adonylo and Oteiz, [4] indicate that $\mathrm{Pb}^{2+}$ intoxication induces an oxidative stress situation in rat brain. It had been previously shown that oxidative stress because of decreased antioxidant function might be the main mechanism involved in brain neurotoxicity induced by $\mathrm{Pb}$-exposure [44-46].
From the previous studies and the present result. It could be suggesting that LA-induced neurotoxicity is mainly by oxidative stress and affecting on neurotransmitter release. In addition, it showed that LA induced neurontoxicity was characterized by various potentially detrimental changes such as decreased NE, DA, 5-HT and 5-HIAA content. The decrease in 5-HIAA content may due to the decrease in 5-HT content.

Grape seeds extract (GSE) contains polyphenols including proanthocyanidins and procyanidins that showed antioxidant and free radical scavengers, being more effective than either ascorbic acid or vitamin E [47-49]. Their effects include the ability to increase intracellular vitamin $\mathrm{C}$ levels, decrease capillary permeability and fragility and scavenge oxidants and free radicals. Several studies have indicated that extracts obtained from grape seed inhibit enzyme systems that are responsible for the production of free radicals $[13,50]$. Red grape seed extract also blocks cell death signaling [51]. Many studies have provided evidence that proanthocyanidin has potent radical scavenging ability, antioxidant properties and significant neuroprotective as well as cardiovascular protective effect [52-54].

Procyanidins are natural botanic polyphenols extracted from grape seeds, with bioactivities such as antioxidation, free radical elimination and cell proliferation stimulation [55]. Recently, there is great evidence that GSE prevents oxidative injury by modulating the expression of antioxidant enzyme systems [56]. The oxidative DNA damage in the brain regions of aged rats was also modulated by GSE administration [19]. GSE has been also shown to be protective against nitrosative/oxidative stress [57], and has exhibited superior. From the present result it is clear that there is improve in neurotransmitters content in the protective and therapeutics group which received GSE. Koga et al. [58] reported that the intake of proanthocyanidins increases the resistance of plasma against oxidative stress and may contribute to physiological functions of plant food through their in vivo antioxidant activities. Feng et al. [59] reported that, treatment with grape seed extract suppresses lipid peroxidation and reduces hypoxic ischemic brain injury in rat. Several studies have suggested GSE has a critical role as neuroprotective [6062]. Through inhibition of calcium signals and nitric oxide formation [63]. From the previous study as well as the present result, it could be concluded that, GSE has a protective and therapeutic role against lead toxicity. This is may be the presence of proanthocyanidins and procyanidins that showed antioxidant and free radical scavengers.

Lead is known to adversely affect many organs, where the liver being one of the major organs involved in the storage, biotransformation and detoxification of toxic substances, is of interest in heavy metal poisoning [64]. 
Lead produces oxidative damage in the liver by enhancing lipid peroxidation and cause liver dysfunction and increase free radical damage [65].

From the present result it is clear that GSE cause decrease in GOT, GPT and LDH which increased as a result of LA treatment. GOT, GPT levels are biomarkers of liver injury with some degree of intact liver function, and the elevated levels of LDH may indicate liver damage.

Cetin et al. [66] reported that grape seed extract may be promising as a therapeutic option in RTx-induced oxidative stress in the rat liver. El-Ashmawy et al. [67] concluded that grape seed extract is a useful herbal remedy, especially for controlling oxidative damages and is considered as a potent protective agent against hepatotoxicity. Several lines of evidence demonstrated that, grape seed proanthocyanidins exhibited in vivo hepatoprotective and anti-fibrogenic effects against liver injury and act as free radicals scavengers and protective liver damage [68-70].

\section{Conclusion}

Protective and therapeutic action of GSE is observed, this may be due to: inhibition of calcium signals and nitric oxide formation, counteracting free radicals, reducing liver toxicity markers. They all contribute to its potential as a modulator of oxidative damage produced by lead acetate. Additional studies are needed to demonstrated GSE efficacy in human.

\section{REFERENCES}

[1] T. I. Lidsky and J. S. Schneider, "Lead Neurotoxicity in Children: Basic Mechanisms and Clinical Correlates," Brain, Vol. 126, 2003, pp. 5-19. doi:10.1093/brain/awg014

[2] M. Pande and S. J. S. Flora, "Lead Induced Oxidative Damage and Its Response to Combined Administration of A-Lipoic Acid and Succimers in Rats," Toxicology, Vol. 177, 2002, pp. 187-196. doi:10.1016/S0300-483X(02)00223-8

[3] A. Garaza, R. Vega and E. Soto, "Cellular Mechanisms of Lead Neurotoxicity," Medical Science Monitor, Vol. 12, No. 3, 2006, pp. RA57-RA65.

[4] V. N. Adonaylo and I. P. Oteiza, "Lead Intoxication Defenses and Oxidative Damage in Rat Brain," Toxicology, Vol. 135, 1999, pp. 77-85. doi:10.1016/S0300-483X(99)00051-7

[5] D. C. Bellinger, "Very Low Lead Exposure and Children's Neurodevelopment," Current Opinion in Pediatrics, Vol. 20, No. 2, 2008, pp. 172-177. doi:10.1097/MOP.0b013e3282f4f97b

[6] H. Gurer and N. Ercal, "Can Antioxidants Be Beneficial in the Treatment of Lead-Poisoning?" Free Radical Biology \& Medicine, Vol. 29, No. 10, 2000, pp. 927-954. doi:10.1016/S0891-5849(00)00413-5

[7] Agency for Toxic Substances and Disease Registry (ATSDR),
"Toxicological Profile for Lead Atlanta," GA: US Department of Health and Human Services, Public Health Service, Agency for Toxic Substances and Disease Registry, 1999.

[8] H. J. Yun, I. Kim, S. Kwon, J. Kang and A. Om, "Protective Effects of Chlorella Vulgaris against Lead-Induced Oxidative Stress in Rat Brains," Journal of Health Science, Vol. 57, No. 3, 2011, pp. 245-254. doi:10.1248/jhs.57.245

[9] J. Yamakoshi, M. Saito, S. Kataoka and M. Kikuchi, "Safety Evaluation of Proanthocyanidin-Rich Extract from Grape Seeds," Food Chemical Toxicology, Vol. 40, No. 5, 2002, pp. 599-607. doi:10.1016/S0278-6915(02)00006-6

[10] J. Gruenwald, B. A. Brendler and C. Jaenicke, "PDR for Herbal Medicines," 3rd Edition, Thomson PDR, Montvale, 2004

[11] Z. Jia, Z. Song, Y. Zhao, X. Wang and P. Liu, "Grape Seed Proanthocyanidin Extract Protects Human Lens Epithelial Cells from Oxidative Stress via Reducing NFкB and MAPK Protein Expression," Molecular Vision, Vol. 17, 2011, pp. 210-217.

[12] S. F. Shenoy, C. L. Keen, S. Kalgaonkar and T. A. Polagruto, "Effect of Grape Seed Extract Consumption on Platelet Function in Postmenopausal Women," Thrombosis Research, Vol. 121, No. 3, 2007, pp. 431-432. doi:10.1016/j.thromres.2007.09.004

[13] T. Maier, A. Schieber, D. Kammerer and R. Carle, "Residues of Grape (Vitis vinifera L.) Seed Oil Production as a Valuable Source of Phenolic Antioxidants," Food Chemistry, Vol. 112, 2009, pp. 551-559. doi:10.1016/j.foodchem.2008.06.005

[14] J. Shi, J. Ya and J. E. Pohorly, "Polyphenolics in Grape Seeds. Biochemistry and Functionality," Journal of Medicinal Food, Vol. 6, No. 4, 2003, pp. 291-299. doi:10.1089/109662003772519831

[15] H. A. H. Khattab, I. Z. A. Abdallah and G. M. Kamel, "Grape Seed Extract Alleviated Reproductive Toxicity Caused by Aluminum Chloride in Male Rats," Journal of American Science, Vol. 6, No. 12, 2010, pp. 1200-1209.

[16] T. I. Lindsky and J. S. Schneider, "Lead Neurotoxicity in Children: Basic Mechanisms and Clinical Correlates," Brain, Vol. 126, No. 1, 2003, pp. 5-19. doi:10.1093/brain/awg014

[17] J. Zhao, J. Wang, Y. Chen and R. Agarwal, "Anti-TumorPromoting Activity of a Polyphenolic Fraction Isolated from Grape Seeds in the Mouse Skin Two-Stage Initiation-Promotion Protocol and Identification of Procyanidin B5-3-Gallate as the Most Effective Antioxidant Constituent," Carcinogenesis, Vol. 20, 1999, pp. 1737-1745. doi:10.1093/carcin/20.9.1737

[18] Iranian Herbal Pharmacopoeia, "Tehran: Deputy for Food and Drug," Iranian Ministry of Health, 2003, pp. 24-25.

[19] M. Balu, P. Sangeetha, G. Murali and C. Panneerselvam, "Modulatory Role of Grape Seed Extract on Age-Related Oxidative DNA Damage in Central Nervous System of Rats," Brain Research Bulletin, Vol. 68, 2006, pp. 469-473. doi:10.1016/j.brainresbull.2005.10.007

[20] M. A. Tangeng, H. Chen, D. K. Lim, A. S. Hume and J. 
K. Ho, "Excitatory Amino Acids and Lead-Induced Neurotoxicity," The Journal of Toxicological Science, Vol. 23, No. 2, 1998, pp. 181-183.

[21] S. D. Ray, D. Patel, V. Wong and D. Bagchi, "In Vivo Protection of DNA Damageassociated Apoptotic and Necrotic Cell Deaths during Acetaminophen-Induce Dnephrotoxicity, Amiodarone-Induced Lung Toxicity and Doxorubicin-Induce Dcardiotoxicity by a Novel IH636 Grape Seed Proanthocyanidin Extract," Research Communications in Molecular Pathology \& Pharmacology, Vol. 107, 2000, pp. 137-166.

[22] I. M. El-Ashmawy, A. F. El-Nahas and O. M. Salama, "Grape Seed Extract Preventsgentamicin-Induced Nephrotoxicity and Genotoxicity in Bone Marrow Cells of Mice," Basic \& Clinical Pharmacology \& Toxicology, Vol. 99, No. 3, 2006, pp. 230-236. doi:10.1111/j.1742-7843.2006.pto_497.x

[23] J. Glowinski and L. L. Iversen, "Regional Studies of Catecholamines in the Rat Brain. I. The Disposition of $[3 \mathrm{H}]$ Dopamine and $[3 \mathrm{H}]$ Dopa in Various Regions of the Brain," Journal of Neurochemistry, Vol. 13, No. 8, 1966, pp. 655-669. doi:10.1111/j.1471-4159.1966.tb09873.x

[24] C. C. Chang, "A Sensitive Method Forspectrofluorometric Assay of Catecholamines," International Journal of Neuropharmacology, Vol. 3, No. 6, 1964, pp. 643-649. doi:10.1016/0028-3908(64)90089-9

[25] A. E. Ciarlone, "Further Modification of a Fluoremetric Method for Analyzing Brain Amines," Microchemical Journal, Vol. 23, No. 1, 1978, pp. 9-12. doi:10.1016/0026-265X(78)90034-6

[26] F. P. Miller, R. H. Cox, W. R. Snodegrass and R. P. Maichel, "Comparative Effect of p-Chlorophenylalanine, pChloroamphetamine and p-Chloro-n-hydroxyindole-3-acetic Acid," Biochemical Pharmacology, Vol. 19, No. 2, 1970, pp. 435-442. doi:10.1016/0006-2952(70)90199-1

[27] S. Reitman and S. A. Frankel, "Colorimetric Method for the Determination of Serum Oxaloacetic and Glutamic Pyruvic Transaminases," American Journal of Clinical Pathology, Vol. 28, 1957, pp. 56-63.

[28] T. H. Khan and S. Sultana, "Antioxidant and Hepatoprotective Potential of Soy Isoflavones against CC14 Induced Oxidative Stress and Early Tumor Events," Indo-Global Journal of Pharmaceutical Sciences, Vol. 1, No. 1, 2011, pp. 39-56.

[29] A. Kornberg, "Lactic Dehydrogenase of Muscle," In: S. P. Colowick, N. O. Kaplan, Eds., Methods in Enzymology, Academic Press, New York, 1955, pp. 441-443.

[30] J. M. Lefauconnier, G. Bernard, F. Mellerio, A. Sebille and E. Cesarini, "Lead Distribution in the Nervous System of 8-Month-Old Rats Intoxicated since Birth by Lead," Experientia, Vol. 39, No. 9, 1983, pp. 1030-1031. doi:10.1007/BF01989787

[31] T. Verina, C. A. Rohde and T. R. Guilarte, "Environmental Lead Exposure during Early Life Alters Granule Cell Neurogenesis and Morphology in the Hippocampus of Young Adult Rats," Neuroscience, Vol. 145, No. 3, 2007, pp. 1037-1047. doi:10.1016/i.neuroscience.2006.12.040

[32] T. Sanders, Y. Liu, V. Buchner and P. B. Techounwou,
"Neurotoxic Effects and Biomarkers of Lead Exposure: A Review," Reviews on Environmental Health, Vol. 24, No. 1, 2009, pp. 15-45. doi:10.1515/REVEH.2009.24.1.15

[33] H. A. Ruff, M. E. Markowitz, P. E. Bijur and J. F. Rosen, "Relationships among Blood Lead Levels, Iron Deficiency, and Cognitive Development in Tow-Year-Old Children," Environmental Health Perspectives, Vol. 104, No. 2, 1996, pp. 180-185.

[34] M. R. Basha, W. Wei, M. Brydie, M. Razmiafshari and N. H. Zawia, "Lead Induced Developmental Perturbations in Hippocampal SP1DNA-Binding Are Prevented by Zinc Supplementation," International Journal of Developmental Neuroscience, Vol. 21, No. 1, 2003, pp. 1-12. doi:10.1016/S0736-5748(02)00137-5

[35] M. E. Gilbert, M. E. Kelly, T. E. Samsam and H. J. Coodman, "Chronic Developmental Lead Exposure Reduces Neurogenesis in Adult Rat Hippocampus but Does Not Impair Spatial Learning," Toxicological Science, Vol. 86, No. 2, 2005, pp. 365-374. doi:10.1093/toxsci/kfi156

[36] D. A. Gidlow, "Lead Toxicity," Occupational Medicine, Vol. 54, No. 2, 2004, pp. 76-81. doi:10.1093/occmed/kqh019

[37] S. V. Verstraeten, L. Aimo and P. I. Oteiza, "Aluminum and Lead: Molecular Mechanisms of Brain Toxicity," Archives of Toxicology, Vol. 82, No. 11, 2008, pp. 789-802. doi:10.1007/s00204-008-0345-3

[38] R. A. Rius, S. Govoni, S. Bergamuschi, L. Luechi and M. Trabucchi, "Mechanisms of the Effect of Lead on Brain Neurotransmission: A Calcium Mediated Action," Science of the Total Envionment, Vol. 71, No. 3, 1988, pp. 441-448. doi:10.1016/0048-9697(88)90216-1

[39] M. J. Mclentosh, P. A. Meredith, M. R. Moore and A. Goldberg, "Action of Lead on Neurotransmission in Rats," Xenobiotica, Vol. 19, No.1, 1989, pp. 101-113. doi: $10.3109 / 00498258909034682$

[40] K. D. Gill, V. Gupta and R. Sandhair, " $\mathrm{Ca}^{2+} /$ CalmodulinMediated Neurotransmitter Release and Neurobehavioural Deficits Following Lead Exposure," Cell Biochemistry \& Function, Vol. 21, No. 4, 2003, pp. 345-353. doi:10.1002/cbf.1030

[41] D. A. Nachshen, "Selectivity of the Ca Binding Site in the Synaptosome $\mathrm{Ca}$ Channels. Inhibition of $\mathrm{Ca}$ Influx by Multivalent Metal Captions," Journal of Genetic Physiology, Vol. 83, 1984, pp. 941-967. doi:10.1085/igp.83.6.941

[42] D. J. Minnema, I. A. Michaelson and G. P. Coopers, "Calcium Efflux and Neurotransmitter Release from Rat Hippocampal Synaptosomes Exposed to Lead," Toxicology and Applied Pharmacology, Vol. 92, No. 3, 1988, pp. 351-357. doi:10.1016/0041-008X(88)90175-5

[43] C. M. Bouton, L. P. Frelin, C. E. Forde, H. A. Godwin and J. Pevsner, "Synaptotagmin I Is a Molecular Target for Lead," Journal of Neurochemistry, Vol. 76, No. 6, 2001, pp. 1724-1735. doi:10.1046/j.1471-4159.2001.00168.x

[44] F. Ozguner, A. Armagan, A. Koyu, S. Caliskan and H. Koylu, "A Novel Antioxidant Tagent Caffeic Acid Phenethyl Ester (CAPE) Prevents Shock Wave-Induced Renal Tubularoxidative Stress," Urological Research, Vol. 33, No. 
3, 2005, pp. 239-243. doi:10.1007/s00240-005-0470-x

[45] J. Wang, J. Wa and Z. Zhang, "Oxidative Stress in Mouse Brain Exposed to Lead," The Annals of Occupational Hygiene, Vol. 50, No. 4, 2006, pp. 405-409.

doi:10.1093/annhyg/mei079

[46] T. El-Masry, A. M. Emara and N. A. El-Shitany, "Possible Protective Effect of Propolis against Lead-Induced Neurotoxicity in Animal Model," Journal of Evolutionary Biology Research, Vol. 3, No. 1, 2011, pp. 4-11.

[47] D. Bagchi, M. Bagchi, S. J. Stohs, D. K. Das, S. D. Ray, C. A. Kuszynski, S. S. Joshi and H. G. Pruess, "Free Radicals and Grape Seed Proanthocyanidin Extract: Importance in Human Health and Disease Prevention," Toxicology, Vol. 148, No. 2-3, 2000, pp. 187-197. doi:10.1016/S0300-483X(00)00210-9

[48] D. Bagchi, S. D. Ray, D. Patel and M. Bagchi, "Protection against Drug- and Chemicalinduced Multiorgan Toxicity by a Novel IH636 Grape Seed Proanthocyanidin Extract," Drugs under Experimental and Clinical Research, Vol. 27, 2001, pp. 3-15.

[49] Y. Yilmaz and R. T. Toledo, "Health Aspects of Functional Grape Seed Constituents," Trends in Food Science \& Technology, Vol. 15, No. 9, 2004, pp. 422-433. doi:10.1016/j.tifs.2004.04.006

[50] W. G. Li, X. Y. Zhang and Y. J. Wu, "Anti-Inflammatory Effect and Mechanism of Proanthocyanidins from Grape Seeds," Acta Pharmacologica Sinica, Vol. 22, No. 4, 2001, pp. 1117-1120.

[51] S. D. Ray, H. Parikh, E. Hickey, M. Bagchi and D. Bagchi, "Differential Effects of IH636 Grape Seed Proanthocyanidin Extract and a DNA Repair Modulator 4-Aminobenzamide on Liver Microsomal Cytochrome 4502E1Dependent Aniline Hydroxylation," Molecular and Cellular Biochemistry, Vol. 218, No. 1-2, 2001, pp. 27-33. doi:10.1023/A:1007272611915

[52] F. Natella, F. Belelli and V. Gentili, "Grape Seed Proanthocyanidins Prevent Plasma Postprandial Oxidative Stress in Human," Journal of Agricultural and Food Chemistry, Vol. 50, No. 26, 2002, pp. 7720-7725. doi:10.1021/jf020346o

[53] G. Sharma, A. K. Tyagi, R. P. Singh, D. C. Chan and R. Agarwal, "Synergistic Anti-Cancer Effects of Grape Seed Extract and Conventional Cytotoxic Agent Doxorubicin against Human Breast Carcinoma Cells," Breast Cancer Research and Treatment, Vol. 85, No. 1, 2004, pp. 1-12. doi:10.1023/B:BREA.0000020991.55659.59

[54] F. L. Zahang, H. Gao and J. M. Wu, "Selective Inhibition by Grape Seed Proanthocyanidin Extract of Cell Adhesion Molecule Expression Induced Evidenced Glycation End Products in Endolhelial Cell," Journal of Cardiovascular Pharmacology, Vol. 48, No. 2, 2006, pp. 47-53.

[55] D. Bagchi, A. Garg, R. L. Krohn, M. Bagchi, M. X. Tran and S. J. Stohs, "Oxygen Free Radical Scavenging Abilities of Vitamins C and E, and a Grape Seed Proanthocyanidin Extract in Vitro," Research in Communications in Molecular Patholology \& Pharmacoliogy, Vol. 95, No. 2, 1997, pp. 179-189.

[56] F. Puiggros, N. Llopiz, A. Ardevol, C. Blade, L. Arola and M. L. Salvado, "Grape Seed Procyanidins Prevent
Oxidative Injury by Modulating the Expression of Antioxidative Enzyme Systems," Journal of Agricultural Food Chemistry, Vol. 53, No. 15, 2005, pp. 6080-6086. doi:10.1021/jf050343m

[57] S. Roychowdhury, G. Wolf, G. Keilhoff, D. Bagchi and T. Horn, "Protection of Primary Glial Cells by Grape Seed Proanthocyanidin Extract against Nitrosative/Oxidative Stress," Nitric Oxide, Vol. 5, No. 2, 2001, pp. 137-149. doi:10.1006/niox.2001.0335

[58] T. Koga, K. Moro, K. Nakamori, J. Yamakoshi, H. Hosoyama, S. Kataoka and T. Ariga, "Increase of Antioxidative Potential of Rat Plasma by Oral Administration of Proanthocyanidin-Rich Extract from Grape Seed," Journal of Agricultural Food Chemistry, Vol. 47, No. 5, 1999, pp. 1892-1897. doi:10.1021/jf9810517

[59] Y. Feng, Y. M. Liu, J. D. Fratkins and M. H. LeBlance, "Grape Seed Extract Suppresses Lipid Peroxidation and Reduces Hypoxic Ischemic Brain Injury in Neonatal Rats," Brain Research Bulletin, Vol. 66, No. 2, 2005, pp. 120127. doi:10.1016/j.brainresbull.2005.04.006

[60] S. Asha Devi, B. K. Sagar Chandrasekar, K. R. Manju- 1 and N. Ishii, "Grape Seed Proanthocyanidin Lowers Brain Oxidative Stress in Adult and Middle-Aged Rats," Experimental Gerontology, Vol. 46, No. 11, 2011, pp. 958964. doi:10.1016/j.exger.2011.08.006

[61] K. Narita, M. Hisamoto, T. Okuda and S. Takeda, "Differential Neuroprotective Activity of Two Different Grape Seed Extracts," PLoS One, Vol. 6, No. 1, 2011, Article ID e14575. doi:10.1371/journal.pone.0014575

[62] R. J. Cady, J. J. Hirst and P. L. Durham, "Dietary Grape Seed Polyphenols Repress Neuron and Glia Activation in Trigeminal Ganglion and Trigeminal Nucleus Caudalis," Molecular Pain, Vol. 10, No. 6, 2010, pp. 1-12.

[63] S. H. Ahn, H. J. Kim, I. Jeong, Y. I. Hong, M. J. Kim, D. J. Rhie, Y. H. Jo, S. J. Hahn and S. H. Yoon, "Grape Seed Proanthocyanidin Extract Inhibits Glutamate-Induced Cell Death through Inhibition of Calcium Signals and Nitric Oxide Formation in Cultured Rat Hippocampal Neurons," BMC Neuroscience, Vol. 3, 2011, pp. 12-78.

[64] D. S. Herman and M. T. V. Geraldine, "Influence of Minerals on Lead-Induced Alterations in Liver Function in Rats Exposed to Long-Term Lead Exposure," Journal of Hazardous Materials, Vol. 166, No. 2-3, 2009, pp. 14101414. doi:10.1016/j.jhazmat.2008.12.070

[65] A. El-Nekeety, A. A. El-Kady, M. S. Soliman, N. S. Hassan and M. A. Abdel-Wahhab, "Protective Effect of Aquilegia Vulgaris (L) against Lead Acetate-Induced Oxidative Stress in Rat," Food and Chemical Toxicology, Vol. 47, No. 9, 2009, pp. 2209-2215. doi:10.1016/j.fct.2009.06.019

[66] A. Cetin, L. Kaynar, I. Koçyiğit, S. K. Hacioğlu, R. Saraymen, A. Oztürk, O. Orhan and O. Sağdiç, "The Effect of Grape Seed Extract on Radiation-Induced Oxidative Stress in the Rat Liver," The Turkish Journal of Gastroenterology, Vol. 19, No. 2, 2008, pp. 92-98.

[67] I. M. El-Ashmawy, S. B. Gad and O. M. Salama, "Grape Seed Extract Prevents a Zathioprine Toxicity in Rats," Phylotherapy Research, Vol. 24, No. 11, 2010, pp. 17101715. doi: $10.1002 /$ ptr. 3200 
[68] M. O. Shin, S. Yoon and J. O. Moon, "The Proanthocyanidins Inhibit Dimethylnitrosamine-Induced Liver Damage in Rats," Archives of Pharmacal Research, Vol. 33, No. 1, 2010, pp. 167-173. doi:10.1007/s12272-010-2239-1

[69] H. A. El-beshbishy, A. M. Mohamadin, A. A. Nagy and A. B. Abdel-Naim, "Amelioration of Tamoxifen-Induced Liver Injury in Rats by Grape Seed Extract, Black Seed Extract and Curcumin," Indian Journal of Experimental
Biology, Vol. 48, No. 3, 2010, pp. 280-288.

[70] F. V. Pinheiro, V. C. Pimentel, K. S. De Bona, G. Scola, M. Salvador, C. Funchal and M. B. Moretto, "Decrease of Adenosine Deaminase Activity and Increase of the Lipid Peroxidation after Acute Methotrexate Treatment in Young Rats: Protective Effects of Grape Seed Extract," Cell Biochemistry and Function, Vol. 28, No. 1, 2010, pp. 89-94. doi: $10.1002 /$ cbf. 1627 